\title{
Development of Learning Media of Animation Video as Learning Sources of Cultural and Craft Arts
}

\author{
Atip Nurharinia ${ }^{\mathrm{a}}$ Yuyarti $^{\mathrm{a}}$ \\ aPrimary School Teacher Education, Education Faculty Sciense, Semarang State University Indonesia \\ Corresponding e-mail: atip.nurharini@mail.unnes.ac.id
}

\begin{abstract}
Personality, creativity and professional skills of primary school teachers should be developed to achieve optimal performance of their tasks in the school, because the teachers have a role and a very important function in shaping the personality of students, in order to develop and prepare the human resources (HR). The result of the first survey conducting was coordinated by elementary art education lecturer team in a primary school showed that the quality of the professional competence of teachers, especially in using of learning media Cultural Arts and Crafts in the primary school needs to be improved. This condition was seen that during arts and crafts learning activities, the primary school teachers did not show professional competence as well as: 1) when the teacher explains and answers to the media questions optimalized. 2) learning media used by teachers in the form of images that are colorless and unattractive. The problems of the research are: 1). What is kind of the learning developmentmedia of animated videos for elementary school teachers in learning Cultural of Arts and Crafts, 2). How effective is the learningmedia of animation video on learning of Cultural Arts and crafts. The purpose of the research is to create a form of learning media of animation video development for primary teachers in learning Cultural Arts and Craft and describe the effectiveness of the learning media of animation video in learning Cultural Arts and Crafts. This research was carried out the activities development in collaboration between teachers, students, and faculty. Teachers, students, and faculty were a team of researchers who sit together to design the form of the learningmedia of animation video. Activities designcreated the media design; furthermore media design was examined in learning activities Arts and Crafts in the school. The techniques of data were retrieved by observation, questionnaire, and documentation. Data were analyzed by using quantitative and qualitative.
\end{abstract}

Keywords: $\quad$ Learning Media Development, Animation video, Arts and Crafts

\section{INTRODUCTION}

The participation of High Education in order to improve the quality of teacher education now day is an important agenda for the task of educational institutions. It is intended for a changing paradigm in learning that does not emphasize the role of the teacher as the main source of learning (teacher center), but active students in learning should take priority (student center). Therefore, itneeds innovative learning as a necessary by involving the use of learning media innovation made by the teachers to realize active learning and fun.

The result of the first survey conducting was coordinated by elementary art education lecturer team in a primary school showed that the quality of professional competence of teachers, especially in using of learning media Cultural Arts and Crafts in the primary school needs to be improved. This condition was seen that during arts and crafts learning activities, the primary school teachers did not show professional competence as well as: 1) learning did not run naturally, the atmosphere was tense, the situation would be forced to conform to a model teacher. 2) Explanation of the material was always from the teacher, so that learning was still teacher center 3) when teachers explained and answered any questions, the media was not optimized. 4) Learning media used by teachers in the form of images that are colorless and unattractive. 5). Time learning was too long, so that there a lot of wasted time. 6) Scenario monotonous sequence of learning materials, so it makes the students bored. Thus, the problems appeared were not yet competent teachers based on their tasks, so the impact does not achieve educational goals optimally. By the existing conditions as those questions arise in our minds, "What the really is the weaknesses of the education system we have lived all this time?"

Based on those problems, the PGSD UNNES Department as one of the program organizers educators has an important role to find the solutions and provide arguments for teachers, especially in the learning of Arts and Culture and Craft in the primary 
school. According to the arts researchers in primary school. Creativity, as well as the professional capabilities of primary school teachers should be developed in order to carry out the tasks optimally at school, because teachers have a role and a very important function in shaping the personality of students, in order to develop and prepare the human resources. all art materials in the curriculum which consists of music, dance, visual arts and crafts arts. From those materials, students are required to be able to know and master, both in terms of knowledge, appreciation, creativity, and creating creation. For the teaching activities, teachers should provide ease of learning for all students, in order to develop potential optimally. With practice a dance artist learns to experience a sense of creative efficacy and with it comes an abiding faith that the creative imagination can be activated, tolerated, and regulated (P Thomson,2011).

This study aims to reformulation that is useful for primary teacher by developing learning media of animation video in the educational unit lessons, especially on the subjects of Cultural Arts and Crafts. Animation video is stir-shaped image of a set of objects (images) are arranged uniformly follow flow of the movement that has been determined at each increment count the time that happened. Image or object that is referred to in the above definitions may include images of human, animal, or in writing. In the process, the creator of animation or better known as the animator must use logical thinking to determine the flow of motion of an object from the first to the final state of the object. To benefit from the static information learners need to mentally extract and integrate necessary elements for the construction of their personal dynamic mental model to understand the given learning task (Babette Park, Stefan Munzer, Tina Sefert, Roland Brunken, 2016)

The topic of this research is the reason researchers to develop learning media of animation video on learning Cultural Arts and Crafts, where their animated video can provide ease of primary students to learn from all multiart. These learning videos can attract attention and provide motivation for elementary students to learn better learn to dance, sing, draw, or make skills. Beside, this animated video can also be easier for students to appreciate because students can feel the illusion of motion on the displayed image. Besides, beneficial for their students use learning media of animation video is also useful for teachers both in terms of the smoothness of learning, efficiency, and effectiveness. The video facilitation was more often considered useful, where students viewed themselves on video, than in the composition course, where students viewed their peers on video (Ali Leijen, Ineke Lam, Liesbeth Wildschut, P RobertJan Simons, Wilfriend Admiral, 2009). Research problems are:

1) What is kind of development of instructional media of animated videos for primary school teachers as a learning source of Cultural Arts and Crafts?

2) How effective is the learning media of animation video of Arts and Culture and Crafts in the primary school.

\section{METHOD}

\subsection{Types of research}

This type of research is research and development or research and development, means research aims to produce a particular product, and examine the effectiveness of these products (Sugiyono 2008: 297). Thus, this study aims to develop the product in the form of learning media such as animation video. This study is the development activities conducted in collaboration between teachers, students, and faculty. Teachers, students, and faculty are a team of researchers who will sit together to design the form of learning media animation video based on the experience, potential and existing conditions. From design activities will produce media design, media design will be further examined in learning activities of Arts and Crafts in the school. The experimentof these activities is accompanied by a process of evaluation and reflection in efforts to improve learning media of animation video.

Researchers conduct a modification of the ten steps. The following research steps and development are modified.

Stage 1: Potential and Problems.

Data about the potential and the problems derived from the results of previous studies or documentation of activities of individuals or institutions report related to learning cultural arts and crafts.

Stage 2: Collection of Information / Data

The data collection are conducted to analyze the needs of media with interviews and administration of questionnaires to students, teachers, and schools that contain grains needs regarding learning media instructional animation video art and craft culture at primary school level

Stage 3: Media Design

Media design are designed based on the analysis of learning needs of media animation video art and 
craft culture at primary school level consisting of the needs of students, teachers, and schools. It means that learning cultural arts and crafts according to media are required and expected by students, teachers, and schools.

Stage 4: Validation Design

Validation design learning media of art animation video, culture and craft is made by an expert or experts to determine the pros and cons.

Stage 5: Revised Media Design

After the design of learning animation of art, culture and craft media video is validated by experts it is known shortcomings so as to improve the design of the media.

Stage 6: Trial Limited

Limited trial use of learning media instructional animation video art, culture and craft carried out in two schools that become the object of research through observation in a limited trial. Stage 7: Revised Media

They have been tested in limited classes held prototype revision of learning media of animation video art and craft culture in order to be an effective medium for learning. Stage 8: Media

After holding a limited user testing and revision, the results of research on the development of this form of learning media instructional animation video art and craft culture in primary school.

\subsection{Research subject}

The subject of research is the main source of research data that have regarding data variables studied (Azwar S, 2004). The object of research is learning media animated video payload cultural arts and crafts. While the test subjects in the study was grade II in Semarang Barat

\subsection{Research Instruments}

There are two kinds necessary:

a. Data on product research, which is about a form of development of learning media animation video on learning cultural arts and crafts including:

1) Data of learning media component of animation video on cultural and crafts arts learning with the observation sheet validator (two course lecturers media)

2) Data of feasibility media of animation video on learning of cultural arts and crafts using observation sheet validator (team lecturer in art) b. Data on the effectiveness of learning media of animation video on learning of cultural arts and crafts including:

1) Analysis results of responses of students and teachers on learning media of animation video on learning cultural arts and crafts with a questionnaire

2) Conducting learning undertaken by teachers with the implementation of learning media animation video on learning cultural arts and crafts, using sheets and documentation observation.

3) Activities of students in learning activities to the implementation of learning media of animation video on learning cultural arts and crafts use observation sheets and documentation

\subsection{Data analysis technique}

Data were analyzed by using quantitative and qualitative. Quantitative data were described by the sample data with the present data through charts, graphs, pie charts and calculations. While qualitative datawere described by data reduction stage, presenting the data and data conclusion. In this stage of data reduction that is analyzed the data overall, then selected for detailed any parts. It was done to facilitate the understanding when it is served. Method presentation of data: the detailed data are presented in tables or graphs, but conclusion is studied by the data, interpret, compare and then draw conclusions.

\subsection{Indicators of success}

Indicators of success of R \& D are:

1) The device is developed in learning media of animation video on learning cultural arts and crafts in primary school is said be valid when the average score of a validator is minimal

2) The effectiveness of learning media of animation video for the Cultural Arts and crafts in primary school averaged category

\section{RESULTS AND DISCUSSION}

\subsection{Media-Based Animation video development}


Media are developed in learning Cultural Arts and crafts include: text that can be understood easily; images are presented attractively and effectively; election mater adapted to the purpose and characteristics of the material, the video displayed can reveal a good learning materials from the body language, expressions, posture, and tone; learning material on the video presented in the form of sound, images, text separately or together; animation is used to load a funny picture, varied, lots of color, motion, and interesting student concentration.

\subsection{Media Experts Validation}

Animation learning media product has been tested for feasibility by two learning media lecturers. Validator assessed the views contained in an animated video based learning media learning Cultural Arts and crafts for grade 2 elementary school. Besides the quality of video, audio, pictures, and animations were also assessed by validator. Media validation ware conducted in November 2014.

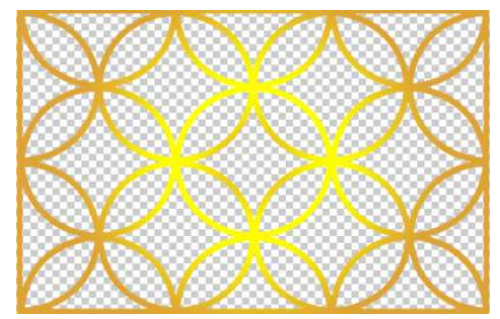

figure 1. animation media of batik

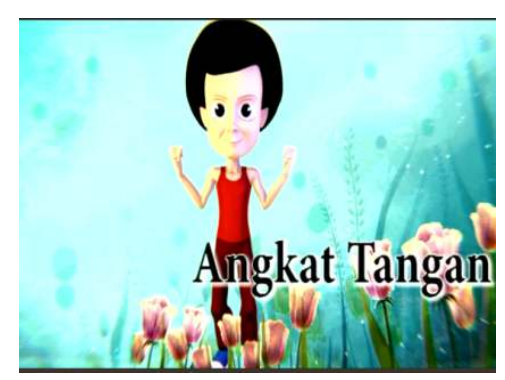

figure 2. Animation media of dance and music
The results of the validation were clearly presented in the following table 1 :

Table 1 result of media expert validation

\begin{tabular}{|c|c|c|c|}
\hline \multirow[t]{2}{*}{ Indicator } & \multicolumn{2}{|c|}{ Score } & \multirow[t]{2}{*}{ Average } \\
\hline & V1 & V2 & \\
\hline Text used can be understood & 4 & 5 & 4,5 \\
\hline $\begin{array}{l}\text { Images are presented } \\
\text { attractively and effectively }\end{array}$ & 4 & 4 & 4 \\
\hline $\begin{array}{l}\text { Election mater adapted to } \\
\text { the purpose and } \\
\text { characteristics of the } \\
\text { materials }\end{array}$ & 5 & 5 & 5 \\
\hline $\begin{array}{l}\text { The video display can reveal } \\
\text { a good learning materials } \\
\text { body language, expressions, } \\
\text { posture, and tone }\end{array}$ & 3 & 4 & 4,5 \\
\hline $\begin{array}{l}\text { Learning material on the } \\
\text { video presented in the form } \\
\text { of sound, } \\
\text { images, text separately or } \\
\text { simultaneously }\end{array}$ & 4 & 4 & 4 \\
\hline $\begin{array}{l}\text { Animation is used to load a } \\
\text { funny picture, varied } \\
\text { lots of color, motion, and } \\
\text { interesting student } \\
\text { concentration }\end{array}$ & 4 & 5 & 4,5 \\
\hline Total Score & 28 & 30 & 29 \\
\hline Value & 80 & 85,7 & 82,9 \\
\hline Category & Good & $\begin{array}{l}\text { Very } \\
\text { Good }\end{array}$ & $\begin{array}{l}\text { Very } \\
\text { Good }\end{array}$ \\
\hline
\end{tabular}

Based on questionnaire validation table 1 , it can be seen that the value obtained was 82.9 so that it can be seen that the learning media animation based on learning cultural arts and craft showed both categories (teaching materials worth using with no revised item 1-2)

\subsection{Validation Expert Content}

Material expertsbecame the validator to examine the products based learning media animation were two experts. Assessment material on this media covering the completeness of information starting material dance, visual, music, crafts, video and audio conformance with the material, and conformity evaluation. The validation results of the validator material presented in table 2 . 
Table 2. result of validation from expert content

\begin{tabular}{|c|c|c|c|c|}
\hline \multirow[t]{2}{*}{ Indicator } & \multirow[t]{2}{*}{ Descriptor } & \multicolumn{2}{|c|}{ Score } & \multirow{2}{*}{ Average } \\
\hline & & V1 & $\mathrm{V} 2$ & \\
\hline \multirow{4}{*}{$\begin{array}{c}\text { Explanation } \\
\text { of learning } \\
\text { materials }\end{array}$} & $\begin{array}{l}\text { Focusing students } \\
\end{array}$ & 4 & 4 & 4 \\
\hline & $\begin{array}{l}\text { Creating the conditions which are } \\
\text { fun }\end{array}$ & & & \\
\hline & $\begin{array}{c}\text { The material is connected with real } \\
\text { life }\end{array}$ & & & \\
\hline & $\begin{array}{l}\text { Material easily understood by } \\
\text { students }\end{array}$ & & & \\
\hline \multirow{6}{*}{$\begin{array}{l}\text { The learning } \\
\text { method }\end{array}$} & Giving the students experience & 4 & 4 & 4 \\
\hline & To provide experience to student & & & \\
\hline & In accordance with the objectives & & & \\
\hline & Characteristics student & & & \\
\hline & Directing for a high-level thinking & & & \\
\hline & Emphasis on student activity & & & \\
\hline \multirow{4}{*}{$\begin{array}{l}\text { Media and } \\
\text { learning } \\
\text { resources }\end{array}$} & Easy to use in learning & 5 & 4 & 4,5 \\
\hline & $\begin{array}{c}\text { Media easily transfer knowledge to } \\
\text { student }\end{array}$ & & & \\
\hline & $\begin{array}{c}\text { Use of media further shortentime } \\
\text { and } \\
\text { materials }\end{array}$ & & & \\
\hline & Media motivating learning & & & \\
\hline \multirow[t]{4}{*}{$\begin{array}{l}\text { Interactive } \\
\text { learning }\end{array}$} & $\begin{array}{l}\text { There are different variations to } \\
\text { support student information }\end{array}$ & 3 & 4 & 3,5 \\
\hline & Provide good stimulus to students & & & \\
\hline & $\begin{array}{l}\text { Make it easy for students to } \\
\text { respond to the material }\end{array}$ & & & \\
\hline & Improve student questions & & & \\
\hline \multirow{7}{*}{$\begin{array}{c}\text { v In } \\
\text { accordance } \\
\text { with the } \\
\text { objective } \\
\text { learning }\end{array}$} & $\begin{array}{l}\text { Facilitate the learning process in } \\
\text { class }\end{array}$ & 5 & 5 & 5 \\
\hline & $\begin{array}{c}\text { Improving the efficiency of the } \\
\text { process } \\
\text { learning }\end{array}$ & & & \\
\hline & $\begin{array}{l}\text { Maintain the relevance of the } \\
\text { subject matter with the aim of } \\
\text { learning }\end{array}$ & & & \\
\hline & Helps concentration of students & & & \\
\hline & Total score & 21 & 21 & 21 \\
\hline & Value & 84 & 84 & 84 \\
\hline & Category & $\begin{array}{l}\text { Very } \\
\text { Good }\end{array}$ & $\begin{array}{l}\text { Very } \\
\text { Good }\end{array}$ & $\begin{array}{l}\text { Very } \\
\text { Good }\end{array}$ \\
\hline
\end{tabular}

According to the table the validation of questionnaire matter expert in Table 2 is known that the overall value was 8.4 this shows an animationbased learning media in learning the art and craft culture were valid and can be used in learning without any revision.

\subsection{DataRespondents}

Student response data was grade 2 elementary school in Semarang Barat with the number 25. Students were provided an assessment of learning media products and materials with 5 number statement. The description of the results of the questionnaire to the student experiment was as follows:
Table 3. description of quistionare

\begin{tabular}{|c|c|c|c|}
\hline \multirow[t]{2}{*}{ Indicator } & \multicolumn{2}{|c|}{ Score } & \multirow[t]{2}{*}{ Average } \\
\hline & School 1 & School 2 & \\
\hline $\begin{array}{l}\text { Do you feel happy } \\
\text { learning by using } \\
\text { video animation? }\end{array}$ & 5 & 4 & 4,5 \\
\hline $\begin{array}{l}\text { By looking at the } \\
\text { animation video, are } \\
\text { you happy spirit to } \\
\text { learning to follow the } \\
\text { cultural arts and } \\
\text { crafts? }\end{array}$ & 5 & 4 & 4,5 \\
\hline $\begin{array}{c}\text { By looking at the } \\
\text { animation video, } \\
\text { whether you easy to } \\
\text { understand } \\
\text { Subject matter? }\end{array}$ & 4 & 4 & 4 \\
\hline $\begin{array}{l}\text { By looking at the } \\
\text { animation video, do } \\
\text { you feel comforted }\end{array}$ & 5 & 5 & 5 \\
\hline $\begin{array}{l}\text { Is an animated video } \\
\text { that aired have } \\
\text { images, sounds } \\
\text { writing, color, clear } \\
\text { story }\end{array}$ & 4 & 4 & 4 \\
\hline Total Score & 23 & 21 & 22 \\
\hline Value & 92 & 84 & 88 \\
\hline Category & Excellent & Excellent & Excellent \\
\hline
\end{tabular}

According to the table 3 student questionnaire, it can be seen that the average value of the students' responses reached 88 with a very good category, it showed the media-based learning animation on learning cultural arts and crafts in an elementary school was valid and can be used in learning without revision.

\subsection{Data Analysis of Expert Media}

Based on the results of questionnaires obtained from media experts can be seen that from the total number of items in the questionnaire, as many as seven grains were used as elements of evaluation. Media experts claimed 1 item having an excellent answer that in point to three. The item was the election materials in accordance with the purposes and characteristics. But, the other sixth items got good category. The sixth item assessed aspects, named: (1). Text used was could understand, (2). Images were presented developed attractive and effective, (3). The video display could provide good communication with the student, (4). The video displayed could reveal learning materials that include body language, expression, gesture and tone, 
(5). Learning material on the video presented in the form of sound, images, or text, separately or together, (6). Animation was used to load a moving image amusing and interesting concentration of students.

Based on the above results it can be concluded that the media experts claim that the development of an animated video based learning media is valid and eligible for use in studying the subject Cultural Arts and crafts for elementary students. Validator to suggest that in the presentation of the volume is not too loud, so that the songs contained in the media does not interfere with the use of media.

\subsection{Data Analysis of Expert Content}

Based on the results of questionnaires obtained from subject matter experts, it is known that from the total number of items in the questionnaire, as many as 5 grains, materials experts assert one item with the answer very well. The Item was: conformity with the learning objectives developed animated video media. Media rated facilitate the learning process in the classroom, improving the efficiency of the learning process, maintain the relevance of the material to the learning objectives, and assist students in learning concentration. As for the indicators comprising: the explanation of learning materials, teaching methods, media and learning resources, interactive learning, expert material stated in either category. Based on the results of the questionnaire analysis validator materials experts, in getting the results there is one indicator that getting enough value that is on interactive learning indicators because the variations shown in the media yet many provide a stimulus for students in learning. The suggestions put forward by the expert validator material, namely motion animation contained in the video should not be too much, so as to further explore the students to find their own creative movement to be more creative.

\section{CONCLUSION}

The resulting product has already beenexamined and revised, so the media were already feasible in use for learning of Cultural and crafts artsfor primary students. Students were motivated and successful in participating in learning activities. Successful development of these views of the media are developed including indicators, among others: the text used that can be understood; the picture presented is developed attractive and effective; video display can provide good communication with the students; video display can reveal learning materials that include body language, expression, posture, and tone; learning material on the video presented in the form of sound, images, or text, separately or together; animation that is used to load a moving image amusing and interesting concentration of students.

\section{REFERENCES}

[1] [1] Ali Leijen, Ineke Lam, Liesbeth Wildschut, P Robert-Jan Simons, Wilfriend Admiral, 2009. Streaming Video to Enhance Students Reflection in Dance Education. Journal homepage:www.elsevier.com/locate/compedu. Computer \& Education 52 ( 2009) 169-176

[2] Arikunto, Suharsimi. 2002. Prosedur Penelitian Suatu Pendekatan Praktek. Cetakan kedua belas. Edisi V. Jakarta: PT Rineka Cipta

[3] Babette Park., Stefan Munzer., Tina Seufert., Roland Brunken, 2016. The Role of Spatial Ability When Fostering Mental Animation in Multimedia Learning; An ATI-study. Journal homepage: www.elsevier.com/locate/comphumbeh

[4] Conroy C. Disability: Creative tensions between drama, theatre and disability arts»// Research in Drama Education: The Journal of Applied Theatre and Performance. 2009. Vol. 14, № 1. P. 1-14.

[5] Hadi, Sumandiyo. 1996. Aspek-aspek Dasar Koreografi Kelompok kelompok. Yogyakarta: Manthili

[6] Hamdani.2011. Strategi Belajar Mengajar.Bandung :Pustaka Setia.

[7] Hendi, Hendratman. 2008. The Magic of Macromedia Director (edisirevisi).Bandung: Informatika Bandung

[8] Jogiyanto. 1990. Analisisdan Desain Sistem Informatika. Pendekatan Terstruktur. Yogyakarta: Andi Offset.

[9] Munandar, Utami. 1992. Mengembangkan Bakat dan Kreativitas Anak Sekolah. Jakarta: PT GramediaWidiasarana Indonesia.

[10]M. Sugiyanto.2004. Analisisdan Desain Aplikasi Multimedia Untuk Pemasaran.Yogyakarta:Andi Offset

[11] .....................2005. Multimedia Alat Untuk Meningkatkan Bersaing.Yogyakarta:Andi Offset.

[12] Nigel, Chapman and Jenny Chapman, Digital Multimedia, Wiley, 2000

[13]Pekerti, Widia, dkk. 2000. Pendidikan Seni Musik / Tari / Drama. UT 
[14] Safaria, Triantoro. Panduan Mencetak Anak Super Kreatif. Jogjakarta: Platinum.

[15] Sedyawati, Edi (ed). 1984. Tari Tinjauan dari Berbagai Segi. Jakarta: Pustaka Jaya.Alfabeta

[16] Sugiyono. 2008. Metode Penelitian Kuantitatif, Kualitatif dan R \& D. Bandung:

[17] Slameto. 2004. Belajar dan Faktor-Faktor yang Mempengaruhinya. Jakarta: PT RinekaCipta. Cet. Ke-4.

[18] Soedarsono, R.M. 1999. Metodologi Penelitian Seni Pertunjukkan dan Seni Rupa. Bandung:MSPI

[19]Ricard Huerta. The Cemetery as a Site for Aesthetic Enquiry in Art Education. Iternational Journal of Education Through Art Vol 12. 2016.

[20] Teresa Eca . 2015. Art, Anthropology and the Gift. Iternational Journal of Education. Vol 12. 2016

[21]P Thomson. 2011. Dance and Creativity. Reference Module in Neuroscience and Biobehavioral Psychology, Encyclopedia of Creativity (Second edition) pages 343-350

[22] O'Reilly K. A playwright reflects on 'alternative dramaturgies' // Research in Drama Education: The Journal of Applied Theatre and Performance. 2009. Vol. 14, № 1. P. 31-35.

[23] William. Raymond. 1981. Cultural, Glasgow. Fantana.Paperback.

[24] Wooster R.. Creative inclusion in commumity theatre: A journey with Odyssey Theatre // Research in Drama Education: The Journal of Applied Theatre and Performance. 2009. Vol. 14, № 1. P. 79-90. 